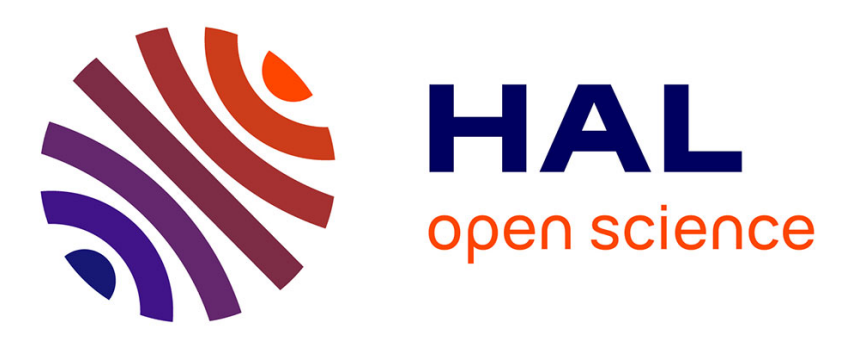

\title{
A novel process for the covalent immobilization of laccases on silica gel and its application for the elimination of pharmaceutical micropollutants
}

Ana Luisa Parra Guardado, Stéphanie Druon-Bocquet, M-P. Belleville, José Sanchez-Marcano

\section{To cite this version:}

Ana Luisa Parra Guardado, Stéphanie Druon-Bocquet, M-P. Belleville, José Sanchez-Marcano. A novel process for the covalent immobilization of laccases on silica gel and its application for the elimination of pharmaceutical micropollutants. Environmental Science and Pollution Research, 2021, 28, pp.25579-25593. 10.1007/s11356-021-12394-y . hal-03216549

\section{HAL Id: hal-03216549 \\ https://hal.science/hal-03216549}

Submitted on 4 May 2021

HAL is a multi-disciplinary open access archive for the deposit and dissemination of scientific research documents, whether they are published or not. The documents may come from teaching and research institutions in France or abroad, or from public or private research centers.
L'archive ouverte pluridisciplinaire HAL, est destinée au dépôt et à la diffusion de documents scientifiques de niveau recherche, publiés ou non, émanant des établissements d'enseignement et de recherche français ou étrangers, des laboratoires publics ou privés. 
A novel process for the covalent immobilization of laccases on silica gel and its application for the elimination of pharmaceutical micropollutants

Ana Luisa Parra Guardado, Stéphanie Druon-Bocquet, Marie-Pierre Belleville, Jose SanchezMarcano*

Institut Européen des Membranes, IEM - UMR 5635, CNRS, ENSCM, Université de Montpellier, Montpellier, France

*Corresponding author:

Tel: +33 467149149; Fax: +33 467149119; Email address: Jose.Sanchez-Marcano@umontpellier.fr 
In the present work, pharmaceutical micropollutants degradation by laccase immobilized on silica through an innovative process is proposed. The influence of different parameters on the immobilization conditions was evaluated by a $2^{3}$ full factorial design, and parameters leading to the highest activity were identified.

5 Under these conditions, laccase activity reached $14 \pm 2 \mathrm{U} \mathrm{g}^{-1}$ of silica with a protein immobilization yield of $635 \%$. The biocatalyst characterization did not show any change in $\mathrm{pH}$ and thermal stabilities but enhanced 7 the long-term storage of laccases. Immobilized T. versicolor laccases were then tested to remove four 8 pharmaceutical micropollutants (amoxicillin, ciprofloxacin, carbamazepine and sulfamethoxazole) in the 9 presence of redox mediators (syringaldehyde, p-coumaric acid, and ABTS). High removal yields (50-100\% according to the pollutant) were obtained within $4 \mathrm{~h}$ of treatment due to the synergistic effect of laccasemediator biotransformation and adsorption on the support. Overall, the pharmaceuticals' removal efficiency was highly influenced by their physicochemical properties; however, the presence of redox mediators impacted not only the oxidation mechanism but also the interactions between the biocatalyst and micropollutants. Finally, the reusability of the biocatalyst was proved during 7 degradation cycles.

Keywords: Laccase; silica preactivation in gas phase; covalent immobilization; redox mediators; pharmaceutical micropollutants. 


\section{INTRODUCTION}

World wide access to pharmaceutical products (PPs) has improved living conditions for the benefit of society. Nonetheless, the broad use of pharmaceuticals also results in their continuous release into the environment as unchanged compounds or metabolites that are inefficiently removed by traditional wastewater treatment plants (WWTPs) (Grandclément et al. 2017). For instance, PPs have been detected in water sources and even in drinking water at concentrations as low as micrograms or nanograms per liter (Ebele et al. 2017). At these low concentrations, pharmaceuticals have the potential to cause short and long-term toxicity, endocrine-disrupting effects in aquatic fauna and human beings. Moreover, the presence of a low quantity of antibiotics in treated wastewaters can also result in antibiotic-resistance in bacteria (Grenni et al. 2018).

To address this environmental issue, advanced processes such as extraction, adsorption on activated carbon, ozonation, Fenton oxidation, and electrochemical techniques have been introduced to WWTPs. In order to meet a high quality of the treated water, these tertiary treatments combined with conventional biological treatments allow the oxidation and/or the removal of PPs. However, limitations such as higher cost, formation of hazardous by-products and low efficiency have been reported (Luo et al. 2014, Teodosiu et al. 2018).

An alternative to chemical and/or physical methods for removing PPs in water is the use of enzymecatalyzed processes. The bioremediation with biocatalysts such as laccases, lipases or tyrosinases can be considered as environmentally friendly processes because they consume fewer chemicals, water, and energy and produce less waste than other chemical oxidative processes (Naghdi et al. 2018). In particular, laccases receive special attention since they can catalyze the oxidation of phenolic and non-phenolic compounds by only using molecular oxygen that is reduced to water. Hence, since the past two decades, several reports have confirmed the effectiveness of laccases to remove a broad range of pollutants, including pharmaceuticals (Morsi et al. 2020). Nevertheless, the depletion of recalcitrant micropollutants needs the addition of redox mediators. When they react with laccase, these mediators lead to highly reactive and stable radical species, thus reacting with micropollutants (Parra Guardado et al. 2019). 
Despite all advantages of enzymatic treatment of wastewaters, the use of laccases in environmental

applications presents some drawbacks related to their limited stability in solution, difficult recovery, and reusability, resulting in high operational costs. However, these disadvantages can be overcome by immobilization (Sheldon and van Pelt 2013). In a recent review, Sakerian et al. (2020) presented the progress made in the development and implementation of immobilized laccase and horseradish peroxidase for the degradation of hazardous micropollutants in water. Different types of supports have been used, such as porous membranes (De Cazes et al. 2014; Nguyen et al. 2016a) as well as solid particulate supports such as silica, magnetic nanoparticles, chitosan microspheres or Amberlite beads (Fortes et al. 2017; Jiang et al. 2005; Patel et al. 2014; Spinelli et al. 2013). Among the different types of carriers, silica-based materials are highly suitable for enzyme immobilization due to their excellent biocompatibility. Moreover, the hydrophilicity of the surface of silica particles can be modulated to promote enzyme immobilization not only by adsorption but also via covalent bonds (Patel et al. 2014; Spinelli et al. 2013; Zdarta et al. 2018).

Immobilization methods and conditions play an important role in the process for which optimization is indispensable to obtain efficient biocatalyst without enzyme leakage through working cycles (Cantone et al. 2013).

Covalent immobilization, which creates strong covalent bonds between the enzyme and the activated groups on the support's surface significantly enhances enzyme reusability and reduces enzyme leaching. Among the potential cross-linkers involved in biocatalyst design, glutaraldehyde is probably the most widely used reagent (Shakerian et al. 2020). Cross-linking reactions are generally carried out in the liquid phase, but limitations related to the diffusion phenomenon of glutaraldehyde in the liquid media may lead to incomplete activation of the immobilization support. Moreover, during activation of supports in liquid phase, glutaraldehyde can not only react with reactive groups of the surface but also with other glutaraldehyde molecules, dimerizing or even polymerizing and then grafting groups could not be accessible to aminogroups of enzymes. In addition, when preparing biocatalysts on a large scale, the disposal of solutions containing unreacted glutaraldehyde remains a serious environmental problem. 
To overcome these drawbacks, a novel process of covalent grafting of laccase onto functionalized silica gel particles has been developed; it involves the activation of the solid support with glutaraldehyde in vapor phase before enzyme grafting. The effects of operating parameters (i.e. concentration and $\mathrm{pH}$ of the enzymatic solution, contact time during the immobilization process) were evaluated by full factorial design. The biocatalyst obtained was then characterized in terms of activity, stability at different $\mathrm{pH}$ and temperature conditions, and long-term storage and compared to the performance of the free enzyme. Finally, immobilized laccase was tested for the degradation of PPs containing different antibiotics (amoxicillin, ciprofloxacin, sulfamethoxazole) and an anti-epileptic (carbamazepine) without or in the presence of redox-mediators ( $p$-coumaric acid, syringaldehyde, 2,2'-azino-bis-(3-ethylbenzothiazoline-6sulphonic acid)) and the reusability of the biocatalyst was also evaluated for several degradation cycles.

\section{MATERIALS AND METHODS}

\subsection{Chemicals and enzymes}

The pharmaceuticals (amoxicillin (AMX), ciprofloxacin (CIP), carbamazepine (CBZ) and sulfamethoxazole $(\mathrm{SMX}))$, the mediators ( $\mathrm{p}$-coumaric acid (PCA), syringaldehyde (SYR), 2,2'-azino-bis-(3ethylbenzothiazoline-6-sulphonic acid) (ABTS)), the cross-linker agent glutaraldehyde (GLU) (25\% (w/v) aqueous solution) and all other chemicals were purchased from Sigma-Aldrich. Stock solutions (100 $\left.\mathrm{mg} \mathrm{L}^{-1}\right)$ of $A M X$ and SMX were prepared in citrate-phosphate buffer $0.1 \mathrm{M}, \mathrm{pH}$ 7. Given the low water solubility of $\mathrm{CIP}$, the antibiotic was pre-dissolved in hydrochloric acid $(0.1 \mathrm{~N})$ and then in citrate-phosphate buffer $\mathrm{pH} 7$. The compounds CBZ, SYR and PCA, were prepared in pure ethanol at a concentration of $1.610^{4} \mathrm{mg} \mathrm{L}^{-1}$ for the pharmaceutical and $115 \mathrm{mM}$ for the mediators. Fresh ABTS solution (5 $\mathrm{mM}$ ) was prepared just before use in citrate-phosphate buffer $\mathrm{pH} 7$.

3-Aminopropyl-functionalized silica gel (particle size $40-63 \mu \mathrm{m}$ ) from Sigma-Aldrich was used as support for laccase immobilization. Three different laccase preparations were tested. Laccase powder from Trametes versicolor (ref 38429, activity $\geq 0.5 \mathrm{U} \mathrm{mg}^{-1}$ and ref 51639, activity $\geq 10 \mathrm{U} \mathrm{mg}^{-1}$ ) (TVL) was purchased from Sigma-Aldrich. TVL ref 51639 was used for the determination of immobilization conditions 
and oxidation reactions with mediators; the rest of the experiments where this enzyme was used were done with TVL ref 38429. Commercial laccase produced by submerged fermentation from Myceliophthora thermophila (59.5 $\mathrm{g} \mathrm{L}^{-1}$ of pure laccase) (MTL) was provided by Novozymes (Denmark). Laccases from Pycnoporus sanguineus CS43 (PSL) kindly provided by Dr. Roberto Parra (ITESM, Mexico) were obtained from a tomato medium as described by Ramirez-Cavazos et al. (2014).

\subsection{Laccase activity essay and protein estimation}

The laccase activity was determined by measuring the oxidation of $1 \mathrm{mM} \mathrm{ABTS}$ at $420 \mathrm{~nm}(\varepsilon 420=$ $36000 \mathrm{M}^{-1} \mathrm{~cm}^{-1}$ ) in $0.1 \mathrm{M}$ citrate-phosphate buffer $(\mathrm{pH} 4)$ at $25{ }^{\circ} \mathrm{C}$ (standard conditions). One enzyme activity unit (U) was defined as the amount of enzyme that oxidized $1 \mu \mathrm{mol}$ of ABTS per min. Immobilized laccase activity was assayed by incubating approximately $8 \mathrm{mg}$ of biocatalyst (dry weight) in a $50 \mathrm{~mL}$ solution of ABTS (1 mM) prepared in a citrate-phosphate buffer $\left(0.1 \mathrm{M}, \mathrm{pH}\right.$ 4) at $25{ }^{\circ} \mathrm{C}$ with continuous stirring. The absorbance at $420 \mathrm{~nm}$ was monitored every minute for 10 minutes. Immobilized laccase activity was expressed in $\mathrm{U} \mathrm{g}^{-1}$ of solid.

Protein concentrations were estimated by Lowry's method using bovine serum albumin as a standard (Lowry et al. 1951). The quantity of protein immobilized on the support was calculated by the difference between the amount of protein initially added and recovered in the supernatant and washing solutions. All spectrophotometric measurements were carried out on a Shimadzu UV-2401PC spectrophotometer.

\subsection{Laccase immobilization}

Laccases were covalently immobilized on the surface of silica gel particles. Firstly, the silica gel particles were activated with GLU in vapor phase. Two different vessels containing respectively $100 \mathrm{mg}$ of 3-Aminopropyl-functionalized silica gel (uniformly dispersed) and $15 \mathrm{~mL}$ of $25 \%(\mathrm{w} / \mathrm{v}) \mathrm{GLU}$ solution were placed into a closed container $(5 \mathrm{~L})$ which was kept at $30^{\circ} \mathrm{C}$ for different periods $(18,30$ and $42 \mathrm{~h})$. Then, the GLU-activated powder was placed in $5 \mathrm{~mL}$ of an enzymatic solution containing 107, 203 or $300 \mathrm{U}$ of one of 
the studied laccases (TVL, MTL, and PSL) in $0.1 \mathrm{M}$ citrate-phosphate buffer $\mathrm{pH} 4.3,5.66$ or 7 . The solution was maintained for $1,1.5$ or $2 \mathrm{~h}$ at $25^{\circ} \mathrm{C}$ under stirring. Finally, the enzyme-activated solid was washed four times with citrate-phosphate buffer $(0.1 \mathrm{M}, \mathrm{pH} 4)$ and stored at $4{ }^{\circ} \mathrm{C}$. The whole process is summarized in Figure 1.

The supernatant from the enzyme grafting process and the solutions produced from the four washing steps were stored for protein determination. The bound protein expressed as a percentage was calculated as the ratio between the amount of protein immobilized and the protein content in the initial enzymatic solution.

\subsection{Experimental design and statistical analysis}

In this study, $2^{3}$ full-factorial experimental design was used to evaluate the influence of three parameters (concentration of enzyme solution $\left(X_{1}\right)$, immobilization time $\left(X_{2}\right)$ and $\mathrm{pH}$ of enzyme solution $\left.\left(X_{3}\right)\right)$ in the activity of immobilized laccase. For each factor, three levels were selected: low level (-1), high level $(+1)$ and basic level (zero) (Table 1). A total of 10 experimental runs, including two replicates at the central point, were carried out in duplicate using MTL as a model enzyme. The obtained responses are shown in Table 2. From experimental data, analysis of variance (ANOVA) was done, and regression coefficients were obtained using Statistica ${ }^{\mathrm{TM}}$ software. Curvature check for the response was assessed and, if significant, considered. Moreover, the proportion of variance explained by the model obtained was given by the multiple coefficient of determination $\mathrm{R}^{2}$.

The regression equation based on the first-order model with three parameters $\left(X_{1}, X_{2}\right.$ and $\left.X_{3}\right)$ and their interactions is presented as follows:

$Y_{i}=b_{0}+b_{1} X_{1}+b_{2} X_{2}+b_{3} X_{3}+b_{12} X_{1} X_{2}+b_{13} X_{1} X_{3}+b_{23} X_{2} X_{3}+b_{123} X_{1} X_{2} X_{3}(1)$

Where $Y_{i}$ represents the predicted response (the activity of immobilized laccase); $X_{1}, X_{2}$, and $X_{3}$ are the coded levels of the factors enzyme concentration, immobilization time and $\mathrm{pH}$ of immobilization. The 
regression coefficients are: $b_{0}$ the constant regression coefficient; $b_{1}, b_{2}, b_{3}$ and $b_{12}, b_{13}, b_{23}$, and $b_{123}$ the regression coefficients for the main and interaction effects, respectively.

\subsection{Attenuated Total Reflectance Fourier Transform Infrared (ATR-FTIR)}

The presence of functional groups on the enzyme and support before and after immobilization was evaluated by FTIR spectroscopy. The analysis was done using a Nicolet "Nexus" spectrometer (ThermoFisher) equipped with a diamond ATR "Golden Gate" plate. The scan range was $400-4000 \mathrm{~cm}^{-1}$ using 128 scans per spectrum with a resolution of $4 \mathrm{~cm}^{-1}$.

\subsection{Characterization of free and immobilized laccase}

Optimum $\mathrm{pH}$ and $\mathrm{pH}$ stability

The $\mathrm{pH}$ of maximum laccase activity (free and immobilized forms) was investigated using $1 \mathrm{mM}$ ABTS in $0.1 \mathrm{M}$ citrate-phosphate buffer $(\mathrm{pH} \mathrm{3-7);} \mathrm{other} \mathrm{reaction} \mathrm{conditions} \mathrm{were} \mathrm{the} \mathrm{same} \mathrm{as} \mathrm{those}$ described in section 2.2. The relative activity was calculated as the ratio between the activity at each $\mathrm{pH}$, and the maximum attained.

The effect of $\mathrm{pH}$ on the enzyme stability was studied by incubating laccase in $0.1 \mathrm{M}$ citratephosphate buffer ( $\mathrm{pH} 4$ and 7 ) at $25^{\circ} \mathrm{C}$ for $24 \mathrm{~h}$. Samples were taken and transferred to standard conditions for activity measurement (see part 2.2). The residual activity was calculated in reference to the initial activity value obtained at each $\mathrm{pH}$.

\section{Optimum temperature and thermostability}

The effect of temperature $\left(15-65^{\circ} \mathrm{C}\right)$ on laccase activity was determined by measuring the activity at the corresponding temperature; other reaction conditions were the same as those described in part 2.2. The relative activity was calculated as the ratio between the activity at each temperature, and the maximum attained. 
183 activity of the laccase exposed to different temperatures $\left(25,45\right.$ and $\left.55^{\circ} \mathrm{C}\right)$ in $0.1 \mathrm{M}$ citrate-phosphate 184 buffer $(\mathrm{pH}$ 7) for different incubation periods and compared with the results obtained with free laccase. 185 Samples were transferred to standard reaction conditions to determine the laccase activity with ABTS, as 186 previously described.

Storage stability

Storage stability of free and immobilized laccase was investigated at $4^{\circ} \mathrm{C}$. For this, both laccase formulations were kept in a citrate-phosphate buffer $(0.1 \mathrm{M} \mathrm{pH} 7)$. The residual activities were obtained after 1 and 2 months by measuring the remaining activity of each enzyme at standard conditions.

\subsection{Oxidation of pharmaceuticals by immobilized laccase}

Degradation experiments were run in $25 \mathrm{~mL}$ glass cells at $25^{\circ} \mathrm{C}$ under continuous stirring to ensure

$\mathrm{O}_{2}$ saturation of the reaction medium and dark conditions to avoid light oxidation. Reaction media (5 $\left.\mathrm{mL}\right)$ contained a mixture of all pollutants in $0.1 \mathrm{M}$ citrate-phosphate buffer $\mathrm{pH} 7$ and one redox mediator (ABTS, PCA, and SYR) at a concentration of $520 \mu \mathrm{M}$. The concentration of each micropollutant in the reaction mixture was fixed at $20 \mathrm{mg} \mathrm{L}^{-1}$ (molar concentration: $55 \mu \mathrm{M} \mathrm{AMX}, 79 \mu \mathrm{M} \mathrm{SMX}$ and $60 \mu \mathrm{M} \mathrm{CIP}$ ) except for CBZ with only $10 \mathrm{mg} \mathrm{L}^{-1}$ (molar concentration: $85 \mu \mathrm{M}$ ). The main objective of this work is the demonstration that this new process of immobilization in vapor phase, result on enough active solids for the degradation of pharmaceuticals, indeed, these relatively high concentrations of micropollutants were chosen to have the necessary precision HPLC-MS of analysis. Reactions started when $2.5 \mathrm{U}(164 \pm 18 \mathrm{mg}$ ) of immobilized TVL was added to the medium. The degradation process was monitored for $4 \mathrm{~h}$ by withdrawing samples at regular times. After sampling, aliquots were centrifuged at $10,000 \mathrm{~g}$ to separate the reaction medium from analyzed with HPLC-MS. 
In order to evaluate the reusability of the biocatalyst, experiments were carried out as described 208 above using SYR as the redox mediator and $2.5 \mathrm{U}$ of immobilized TVL. The reaction was followed for $2 \mathrm{~h}$ 209 (one cycle). At the end of each cycle, the reaction solution was separated from immobilized TVL by centrifugation, filtered and immediately analyzed with HPLC-MS. $10 \mathrm{~mL}$ of citrate-phosphate buffer $(0.1 \mathrm{M}$, $\mathrm{pH}$ 7) was added to the TVL-activated solid and after mixing the solid was recovered by centrifugation. This washing procedure was repeated three times, and afterwards, the TVL-activated solid was recovered and used for a new cycle of degradation in the same conditions as described above. The biocatalyst was reused for a total of 9 cycles. Enzymatic degradation was calculated considering the initial and final concentration of micropollutants in the reaction solution for each cycle.

All experiments were carried out by duplicate and control without immobilized enzyme nor mediator, control with only 3-Aminopropyl-functionalized silica particles and control with inactive immobilized enzyme and mediator were run in parallel to assess the role of the immobilized enzyme on the removal of the pharmaceuticals except for biocatalyst reusability where only control with inactive immobilized enzyme and mediator was run.

\subsection{HPLC-MS analysis}

Determination of pharmaceuticals concentration was carried out on an HPLC Alliance-Waters e2695 separations module coupled to a MS Micromass Quatro micro API (tri-quadripole) detector and a and (B) 100\% methanol. The gradient program was set as follows: $0-3 \mathrm{~min}, 100 \%$ (A); $3-8 \mathrm{~min}, 100 \%$ (B) and 8-15 min, $100 \%$ (A). 
233 immobilization of laccase. This support was selected since the immobilization of the enzymes on its surface 234 is rapid and easy due to its porous structure (60 ̊ pore size), large specific surface area $\left(550 \mathrm{~m}^{2} \mathrm{~g}^{-1}\right)$ and 235 content of amino groups $\left(\sim 1.05 \mathrm{mmol}\right.$ of $\left.\mathrm{NH}_{2} \mathrm{~g}^{-1}\right)$. Indeed, these functional groups allow the establishment 236 of covalent bonds between primary amines on the enzyme and the support thanks to the use of a bifunctional agent like glutaraldehyde (GLU) (Cantone et al. 2013). Moreover, the glutaraldehyde activation of the silica support that exhibited a high density of amino groups (i.e. $1.5 \mathrm{NH}_{2}$ per $\mathrm{nm}^{2}$ ) leaded to a heterofunctional support. The surface properties of such support offer the possibility to immobilize enzyme through covalent bonds with glutaraldehyde and via ionic exchange or hydrophobic interactions (Barbosa et al. 2013). According to Barbosa et al. (2013), as ionic exchange with amino groups occurs more rapidly than covalent bonds, there is no guarantee that all the enzymes that remained on the support were covalently grafted. Generally, glutaraldehyde activation is carried out in a liquid phase when the solid carrier is submerged in a liquid solution of GLU for a determined time. Nonetheless, while working with small size supports ( $\mu \mathrm{m}$ to $\mathrm{nm}$ ), good dispersion in the GLU solution must be guaranteed to avoid potential agglomeration of the particles and uneven deposition of GLU on the support, which could lead to low immobilization yields. In the present study, it was chosen to perform the covalent immobilization of laccases using GLU in vapor phase (see section 2.3). The silica particles and $25 \%$ GLU solution were kept in the same closed vessel at $30^{\circ} \mathrm{C}$ for different periods. The relatively high volatility of GLU at $30^{\circ} \mathrm{C}$ ensures its evaporation leading to the deposition of the activating agent on the support as confirmed by the change in color of silica particles (they turn orange). In addition, thanks to the dry environment, the agglomeration of the activated particles has been avoided. GLU vapor cross-linking technique is often used to fabricate biosensors and modify nanofibrous materials (i.e. water insolubility property) (Anh et al. 2002; Destaye et al. 2013). From our knowledge, this is the first investigation where the vapor phase deposition of GLU is used for the immobilization of enzymes onto silica gel particles for bioremediation purposes. 
particles turned from white to dark orange, confirming the formation of aldimines (Schiff linkage $(=\mathrm{CHN}=)$ between the free amino groups of silica particle and glutaraldehyde and thus the covalent grafting of laccases (George et al. 1984). Nevertheless, results of activity measurement showed that short activation periods $(18 \mathrm{~h})$ yielded a higher specific activity of the immobilized enzyme (Table S1, Supporting Information (SI)). Therefore, GLU activation during $18 \mathrm{~h}$ was chosen to carry out all further experiments.

To determine the immobilization conditions for the novel process, a design of experiments (DOE) approach was applied to evaluate the parameters influencing and improving MTL immobilization. A $2^{3}$ full factorial design was performed where the range of variation of each level was chosen based on theoretical considerations and preliminary experiments. The factors evaluated by the experimental design were the concentration of enzyme solution, time of immobilization and $\mathrm{pH}$ of enzyme solution, while the activity expressed by immobilized laccase $\left(\mathrm{U} \mathrm{g}^{-1}\right.$ solid) was considered as the response variable. It is worth noting that GLU time of contact was not considered in the present design since its influence on the response was not significant (data not shown). Thus, a total of 10 experiments fully replicated were performed, and experimental responses are presented in Table 2.

Using the experimental data and by applying multiple regression analysis, a first-order model predicting the response was obtained:

$Y_{i}=3.45-0.49 X_{1}+0.44 X_{2}+0.80 X_{3}-0.33 X_{1} X_{2}-0.50 X_{1} X_{3}-0.64 X_{1} X_{2} X_{3}(2)$

Table 3 shows the analysis of variance of parameters (ANOVA) and their interactions with statistical significance. The model has a relatively good fit as expressed by the correlation coefficient $\left(R^{2}=0.908\right)$, meaning that the regression model explains $90 \%$ of the total variation of the response, while the residues explain the other $10 \%$. However, the model presented significant curvature $(p=0.003)$ suggesting that the data would be better fitted by another type of design, such as Response Surface Methodology (RSM). Nonetheless, the main objective of this work was to study the influence of the chosen parameters on the response, and for this, the first-order model regression was sufficient, so the model was accepted. 
value below 0.05 , with a confidence level higher than $95 \%$ were considered statistically significant for the

immobilization process. In this sense, it is important to mention that the final model represented by Eq. 2

was run excluding insignificant effects (factors and interactions), as presented in Table 3. The influence of

each factor and how they affected the response is expressed in the model's equation and is given by the

coefficient of each factor and interaction. The greater the absolute value of the coefficient, the higher its

influence on the response. Thus, from Eq. 2 the factors were ranked regarding their significance:

$X_{3}(+)>X_{1} X_{2} X_{3}(-)>X_{1} X_{3}(-)>X_{1}(-)>X_{2}(+)>X_{1} X_{2}(-)$

The most significant factor affecting the activity of immobilized MTL laccase was the $\mathrm{pH}$ of the enzyme solution used for immobilization. The model shows that the response was positively affected when the $\mathrm{pH}$ increased from 4.33 to 7 . The optimal $\mathrm{pH}$ of immobilization should be that one promoting the nucleophilic attack of enzyme reactive groups to the GLU activated support (Pezzella et al. 2014). According to Spinelli et al. (2013), neutral or basic conditions promote GLU crosslinking kinetics whereas acidic ones result favorably in the formation of covalent bonds. However, given the low stability of GLU groups at acidic or alkaline $\mathrm{pH}$ values, immobilization involving GLU is usually favored at neutral conditions (Barbosa et al. 2013). At these pH values, covalent bonds are established with the terminal amino groups in the protein; but with highly activated glutaraldehyde supports, covalent enzyme-support bonds can be created with other nucleophile groups of the protein leading to a multipoint covalent attachment (Spinelli et al. 2013; Barbosa et al. 2013).

In addition, it is well-known that $\mathrm{pH}$ also affects the stability of enzymes. In the case of MTL, the enzyme keeps $100 \%$ of the initial activity for 24 hours at room temperature under neutral pH (Lloret et al. 2010). Moreover, Jiang et al. (2005) also reported pH 7 as the optimal value for the immobilization of a PSL laccase on magnetic chitosan microspheres. These authors reported that this laccase presented low activity and protein loading at more acidic conditions and suggested that the low stability and denaturation of the enzyme as well as the degradation of the support, were at the origin of this behavior.

The second and third more significant variables in the model were the interactions among the three studied factors and the interaction of laccase concentration and $\mathrm{pH}$ of immobilization, both interactions 
negatively affecting the response. For example, it was observed that when enzyme concentration and $\mathrm{pH}$ were at a low level (107 U and pH 4.33 respectively), the activity of immobilized MTL laccase decreased. The same would be expected if both parameters are present at their high level $(330 \mathrm{U}$ and $\mathrm{pH} 7$, respectively, see Table 2). The high and positive coefficient value probably causes such effect for $\mathrm{pH}$. Thus, in order to obtain a more active biocatalyst, enzyme concentration should be set at $107 \mathrm{U}$ and $\mathrm{pH}$ at 7 .

The concentration of enzyme was another parameter that influenced the response negatively. Low amounts of enzymes led to a higher biocatalyst activity with values up to 5.9 and $7.2 \mathrm{U} \mathrm{g}^{-1}$. This behavior was also observed by Fortes et al. (2017) for the immobilization of laccase (Novozym ${ }^{\circledR} 51003$ ) on magnetic nanoparticles, and it was attributed to the saturation of the support by the enzyme. An excess of the enzyme on the support may lead to a lack of intermolecular space resulting in mass transfer limitations that affect the dispersion of substrate and products.

On the other hand, the immobilization time positively influenced laccase immobilization; the active beads obtained after 2 hours of grafting showed almost twice as much activity (assays 2 and 4 in Table 2). Immobilization time is also a crucial variable for the whole process. Whereas too short contact time can result in a limited amount of laccase molecules reacting with the solid, too long immobilization periods lead to oversaturation of the support, causing the before mentioned mass transfer limitations that result in lower activity (Zheng et al. 2016). In this work, longer immobilization time allowed most of the aldehyde groups to react with the amino-groups in laccase, resulting in a biocatalyst with considerable higher activity.

Finally, the last significant parameter was the interaction between laccase concentration and immobilization time with a negative effect. According to the model, a less active biocatalyst would be expected when immobilization time and laccase concentration are either at their low (1 $\mathrm{h}$ and $107 \mathrm{U}$ ) or high levels ( $2 \mathrm{~h}$ and $300 \mathrm{U})$.

From the obtained model we can conclude that the best conditions that maximize immobilized laccase activity are GLU activation time of $18 \mathrm{~h}, 107 \mathrm{U}$ of the enzyme, $2 \mathrm{~h}$ of grafting and $\mathrm{pH} 7$. Therefore, these conditions were selected as the immobilization parameters for all further experiments. 
The new immobilization process successfully developed for the immobilization of MTL was then 340 implemented with TVL and PSL. Immobilization protocol was carried out according to the optimal 341 conditions previously established. Nevertheless, Barrios-Estrada et al (2018) have reported that pH 5 was 342 the optimal for TVL and PSL immobilization on ceramic membranes where a cross-linked gelatin was 343 previously deposited. Indeed, some trials of immobilization at pH 5 were carried out with TVL and PSL; but 344 the results shown a similar activity when compared with immobilization at pH 7. Therefore, Table 4 only 345 reports the immobilization yield and the activity of the three immobilized laccases prepared at $\mathrm{pH}$. 346 Among the three enzymes, TVL yielded the highest specific activity with $13.6 \mathrm{U} \mathrm{g}^{-1}$ biocatalyst and retained 347 the highest amount of protein (35\%). Similar specific activity values (15.8 $\mathrm{U} \mathrm{g}^{-1}$ and $17 \mathrm{U} \mathrm{g}^{-1}$ respectively) 348 were obtained for the covalent immobilization of laccase from C. unicolor C-139 on silica beads at pH 5 (Songulashvili et al. 2012) and M. thermophila laccase on Eupergit C carrier at pH 7 (Lloret et al. 2012).

In the case of MTL, a large quantity of protein is bound to the support, as suggested by the value of immobilization capacity $\left(38 \mathrm{mg} \mathrm{g}^{-1}\right)$. However, the resulting active beads showed relatively low activity. This 352 is probably due to the age of the commercial preparation of MTL (provided by Novozymes 5 years ago). 353 Since the residual activity was less than $2 / 3$ of the initial activity, a high commercial preparation volume 354 was required to prepare the enzyme solution. Thus, the resulting solution contained large amounts of 355 low activity.

Among the different type of active solids, active beads prepared with PSL reported the lowest activity with only $0.76 \mathrm{U} \mathrm{g}^{-1}$. These low activities may have resulted from the presence of impurities in the enzymatic extract. Indeed, Ji et al. (2017) observed a poor performance when they immobilized a crude laccase extract from $P$. ostreatus on titania particles. These authors suggested that the functionalized carrier could have been buried by the non-enzyme components present in the extract, which led to lower enzyme loading and activity. According to their investigation, dilution of the crude extract before 363 immobilization significantly improved laccase loading and apparent activity of the biocatalyst by reducing 364 the competitive effect between the enzyme and the other components to attach to the support. In this 
study, PSL and MTL extracts were diluted 2 and 9 times, respectively, prior to immobilization; it was probably not enough to make the solid surface more accessible to enzymes which is more evident in the case of PSL.

Overall, beads prepared with TVL showed the best results in terms of immobilization yield and activity. Therefore, TVL was chosen to carry out the next stages of the study.

\subsection{Characterization of free and immobilized TVL}

Characterization of the resulting biocatalyst is important due to the shift in optimum operating conditions that can occur after immobilization. This change is basically due to the interactions between the support and enzyme that usually change the biocatalyst conformation. Successful immobilization can lead to an enzyme showing increased stability towards harsh environmental conditions compared to the soluble form (Rodrigues et al. 2013). In this section, Fourier Transform Infrared spectroscopy (ATR-FTIR) characterization was done to confirm the presence of laccase on the surface of the carrier due to covalent bonding. Moreover, free and immobilized laccase activity and stability were compared at different $\mathrm{pH}$, temperature and long-term storage values.

\section{Fourier Transform Infrared spectroscopy (ATR-FTIR) characterization}

The immobilization of TVL on silica gel microparticles was assessed by ATR-FTIR. Figure 2 presents the FTIR spectra of free TVL, untreated 3-Aminopropyl-functionalized silica gel and the silica gel particles after laccase immobilization. Characteristic bands of free laccase were observed at $3300 \mathrm{~cm}^{-1}(\mathrm{OH}$ and $\mathrm{NH}$ vibrations), $2900 \mathrm{~cm}^{-1}$ (CH stretch), $1630 \mathrm{~cm}^{-1}$ (attributed to a secondary amide structure-CONH), $1350 \mathrm{~cm}^{-1}$ (CN stretching of amines) and $1100 \mathrm{~cm}^{-1}$ (COC groups) in agreement with the literature (Tavares et al. 2015). Pristine silica gel particles presented a strong band centered at $1050 \mathrm{~cm}^{-1}$ attributed to the vibration of Si-O-Si and two weak peaks at $1616 \mathrm{~cm}^{-1}$ and $1523 \mathrm{~cm}^{-1}$ corresponding to $\mathrm{Si}-\mathrm{OH}$ and primary amine $\mathrm{NH}$ groups. After laccase immobilization, the FTIR spectrum still showed the characteristic bands of silica gel 
particles. However, the specific signals from the enzyme at $1400 \mathrm{~cm}^{-1}$ and $1600 \mathrm{~cm}^{-1}$ on the active silica spectrum confirm the immobilization of the enzyme on the support. Nonetheless, the decrease in vibration bands attributed to the enzyme suggests that laccase was immobilized in low quantity as confirmed by the immobilization capacity value (13.5 $\mathrm{mg}$ protein $\mathrm{g}^{-1}$ silica) calculated for TVL (Table 4).

\section{Optimum $\mathrm{pH}$ and temperature}

Optimal pH for free and immobilized TVL was investigated in the $\mathrm{pH}$ range from 3 to 7 in $0.1 \mathrm{M}$ citrate-phosphate buffer at room temperature. From Figure $3 \mathrm{a}$, it can be observed that $\mathrm{pH}$ did not significantly influence the activity of the immobilized enzyme in comparison to the free enzyme. Both immobilized and free laccase showed a similar activity versus $\mathrm{pH}$ profile, except at $\mathrm{pH} 6$ where the relative activity of immobilized laccase was on average $15 \%$ lower than that one of the free enzymes. Moreover, both free and immobilized systems exhibited the maximum activity at pH 3. According to Jiang et al. (2005), immobilization can create a microenvironment surrounding the enzyme where an unequal partitioning of $\mathrm{H}^{+}$and $\mathrm{OH}^{-}$concentrations, due to electrostatic interactions with the support, can cause a change in optimal $\mathrm{pH}$. The fact that a shift in optimal $\mathrm{pH}$ did not occur in this study suggests that electrostatic interactions were not involved during immobilization, and the process was rather carried out through covalent interaction, as observed in other investigations (Misra et al. 2014).

The effect of temperature on TVL activity of the free and immobilized enzyme was investigated in the range $15-65^{\circ} \mathrm{C}$ under standard conditions $(0.1 \mathrm{M}$ citrate-phosphate buffer $\mathrm{pH}$ 4). The optimum temperature for free and immobilized laccase was $55^{\circ} \mathrm{C}$ (Figure $3 \mathrm{~b}$ ). The Immobilized enzyme showed a broader profile displaying relative activities up to $16 \%$ higher than free enzyme for all temperatures tested and retained more than $80 \%$ of the activity in the range from 35 to $65^{\circ} \mathrm{C}$; except at $15^{\circ} \mathrm{C}$ where free enzyme showed higher relative activity than the immobilized form (58 and $48 \%$ respectively). 
Industrial applications often require enzymes showing high stability at extreme operational

conditions (e.g. $\mathrm{pH}$, temperature, presence of organic solvents). Therefore, $\mathrm{pH}$ and thermal stability of immobilized TVL were evaluated at $\mathrm{pH} 4$ and 7 and $25^{\circ} \mathrm{C}$ for $24 \mathrm{~h}$ and compared to that of the free enzyme.

421 Results reported in Figure 4a confirms that laccases are very stable at pH 7; deactivation profiles obtained at $\mathrm{pH} 7$ were nearly similar for both biocatalyst forms ( $0 \%$ and less than $10 \%$ of deactivation in $24 \mathrm{~h}$ for immobilized and free enzyme respectively). Moreover, it can be noted that immobilization enhances laccase stability in the case of short storage duration (i.e. up to $6 \mathrm{~h}$ ) at $\mathrm{pH} 4$. After $6 \mathrm{~h}$ of incubation residual activity of the free enzyme was equal to $64 \%$, while immobilized enzymes retained $87 \%$ of the initial activity. Similar enhancement on stability at acidic $\mathrm{pH}$ was observed when laccase was immobilized on granular activated carbon (Nguyen et al. 2016b) and fumed silica microparticles (Gamallo et al. 2018). The authors stated that improved stability could be related to the rigidification of the enzyme after immobilization, which makes it less susceptible to denaturation.

Nevertheless, at the end of $24 \mathrm{~h}$, the residual activity of free and immobilized laccase was practically the same (56 and $61 \%$ respectively). However, the decrease in activity may be due to the release of noncovalently immobilized enzymes. Indeed, as suggested by Barbosa et al. (2013), the activated silicate particles can be considered as hetero-functional support where laccases can also be immobilized through non-covalent interactions (i.e. ionic or hydrophobic interactions) which can be affected by acidic conditions. Thermostability was evaluated when both free and immobilized (Figure $4 b$ ) laccases were incubated in citrate-phosphate buffer $(\mathrm{pH} 7)$ at selected temperatures in the range from 25 to $55{ }^{\circ} \mathrm{C}$. It was observed that the activity of immobilized laccase at $45^{\circ} \mathrm{C}$ and $55^{\circ} \mathrm{C}$ dropped more rapidly than that of the free enzyme within the first $4 \mathrm{~h}$ (Figure $4 \mathrm{~b}$ ). However, for longer incubation times at $55^{\circ} \mathrm{C}$, the residual activity of immobilized enzymes remained constant (around 25\%), while those of free enzymes continued decreasing to reach $6 \%$ after $24 \mathrm{~h}$ of incubation. Incubation at $45^{\circ} \mathrm{C}$ resulted in a similar loss of activity for both free 441 and immobilized laccases with residual activity values of $45 \%$ and $52 \%$, respectively, after $24 \mathrm{~h}$. At $25^{\circ} \mathrm{C}$, low 442 thermal inactivation was observed with less than $10 \%$ loss on activity for both free and immobilized 443 laccases. 
Overall, results showed that the immobilization of TVL on silica particles did not improve the

enzyme's thermostability. A similar observation was reported by Fortes et al. (2017) for the thermal stability of Asperguillus oryzae laccase immobilized on magnetic nanoparticles at $60^{\circ} \mathrm{C}$. These authors observed a higher kinetic constant of enzyme deactivation for the immobilized enzyme than for the free form. Even if immobilization can be considered as a powerful tool to improve enzyme stability, it is evident that the preparation protocol played an important role in the poor stability increase observed in this study. For instance, Sanchez et al. (2016) demonstrated that two different immobilized preparations of bovine trypsin treated at similar inactivation conditions suffered very different conformational changes and, therefore, different residual activity. In fact, catalytic capacity is closely related to the 3D structure of the enzyme which can be drastically impacted by high temperatures (Tavares et al. 2015). The fast thermal inactivation of immobilized TVL compared to the free TVL could be attributed to faster or more drastic changes in the enzyme structure, but it can also be due to enzyme desorption (Tavares et al. 2015; Galvão et al. 2018). A new set of experiments would be necessary to confirm the phenomenon behind the low thermostability observed in this investigation.

\section{Storage stability}

To assess storage stability of both free and immobilized enzymes, a solution of free enzymes (152 U $\mathrm{mL}^{-1}$ ) and active beads $\left(100 \mathrm{mg} \mathrm{mL}^{-1}\right)$ were kept at $4^{\circ} \mathrm{C}$ in citrate-phosphate buffer $(0.1 \mathrm{M}, \mathrm{pH} \mathrm{7})$, and residual activity was measured after one and two months. Results showed that immobilized laccase retained $72 \%$ and $47 \%$ of its initial activity after one and two months of storage, respectively. In contrast, free laccase's residual activity, which was around $44 \%$ at the end of the first month, could no longer be measured after two months of storage. These results confirm that covalent attachments improve enzyme stability by reducing the occurrence of changes in the active conformation of the immobilized enzymes.

\subsection{Oxidation of pharmaceuticals by immobilized laccase}


At first, reactions were carried out in a batch reactor by adding only the immobilized biocatalyst to

the micropollutant solution. After $48 \mathrm{~h}$, no significant bio-oxidation was observed for any pharmaceutical confirming the recalcitrance of these micropollutants to laccase degradation, as already reported with free enzymes by Parra Guardado et al. (2019). These authors attributed the low removal to the complex chemical structure of the compounds.

In view of improving the removal of the selected pharmaceuticals, redox mediators were added to the reaction media. Redox mediators are compounds that laccase can easily oxidize resulting in the production of radical species with higher oxidative capacity than the laccase itself. In this work, the compounds SYR, PCA, and ABTS were chosen since they have already demonstrated to enhance the oxidation of AMX, SMX, and CIP in free enzyme systems (Parra Guardado et al. 2019).

Time course degradation for the pharmaceuticals studied by immobilized laccase-mediator systems and the effect of the adsorption-based removal by the inactivated laccase immobilized on the same support is shown in Figure 5. First of all, we can notice that for AMX (Figure 5a) and SMX (Figure 5b), the decrease in the concentration observed by the enzymatic reaction is higher than the adsorption phenomenon. Regarding CIP, the decrease observed is similar except when ABTS is used as a mediator; in this case, the adsorption observed is relatively lower. Finally, for CBZ, the decrease of the concentration is similar for adsorption or bio-reaction experiments.

If only adsorption results are considered (open symbols), we can observe an increase in the adsorption phenomenon during the first 30 minutes, then the concentration stabilizes. Moreover, adsorption depends on the mediator used; $40 \%$ of AMX, SMX, and CIP are adsorbed in the presence of PCA and SYR, whereas when ABTS is used as a mediator, the adsorption phenomenon decreases $(<20 \%$ for AMX and $\mathrm{CIP}, 30 \%$ for SMX). CBZ is the highest adsorbed molecule, around $50 \%$, regardless of the mediator used. It is important to notice that the adsorption of the antibiotics by the pristine silica support was less than $10 \%$ for AMX, SMX and CIP and only $18 \%$ of CBZ after $4 \mathrm{~h}$ (Fig. S1, SI).

The removal of organic pollutants via adsorption by the support has been extensively described. For example, Cabana et al. (2009) reported adsorption values from 40 to $60 \%$ for nonylphenol, bisphenol A and 
triclosan by inactivated laccase covalently immobilized on Celite R-633 supports. CIP hydrochloride adsorption reached $77 \%$ when mesoporous carbon nanospheres were used (Shao et al. 2019). Inactive immobilized laccase on Magnetic $\mathrm{Cu}^{2+}$-chelated silica particles removed 38\% of pentachlorophenol by adsorption (Wang et al. 2012). As discussed above, the highest adsorption observed was for CBZ, which has the highest octanol/water partition coefficient ( $\left.\log \mathrm{K}_{\mathrm{ow}}=2.45\right)$ and the lowest water solubility $\left(78 \mathrm{mg} \mathrm{L}^{-1}\right.$ ) (Celiz et al. 2009). Regarding the antibiotics, lower adsorption for AMX and SMX would be expected as judged from their corresponding partition coefficients and water solubility values: 0.87 and $3400 \mathrm{mg} \mathrm{L}^{-1}$ for AMX and 0.89 and $610 \mathrm{mg} \mathrm{L}^{-1}$ for SMX (Wishart et al. 2006). In the case of CIP, a Log Kow value of 0.28 but an extremely low solubility (less than $1 \mathrm{mg} \mathrm{L}^{-1}$ ) in water explains its high adsorption (Wishart et al. (2006).

As already stated, in the presence of ABTS, the adsorption of CIP and AMX was remarkably different compared to SYR or PCA control reactions. If attention is paid to Figure 5, ABTS seemed to reduce the proportion of micropollutants adsorbed on the support in comparison to the other mediators. These results might be explained by assuming interactions or adsorption of ABTS on inactivated enzymes leading to a competition for adsorption sites between antibiotics and mediators.

Although part of the observed elimination was caused by adsorption on the solid carrier, the action of the immobilized enzyme-mediator system in removing the target pharmaceuticals was evident for SMX and AMX. In the presence of SYR, complete transformation of the antibiotic SMX was achieved within $4 \mathrm{~h}$ of treatment (Figure 5b). The use of ABTS and PCA also allowed removing 53\% and 54\% of SMX, respectively, in 30 minutes. Regarding $\mathrm{AMX}$, the three mediators led to similar results with transformation yields in the range of 78-89\%, as observed in Figure 5a. According to Figure 5c, removal of CIP occurred within the first 30 minutes of treatment, and no effect of SYR and PCA mediators in the antibiotic's removal was observed; the decrease of CIP concentration was attributed to adsorption on the support. However, in ABTS presence, CIP removal was due to enzymatic degradation as shown by the control. CBZ removal was entirely by adsorption, as confirmed by control reactions with inactivated biocatalyst.

Overall, results indicate that removal of these micropollutants by immobilized laccase-mediator systems is both compound and mediator dependent. A marked difference in the removal of SMX, AMX and 
at some point of CIP and CBZ was observed. The main reason could be the difference in laccase-mediator 522 oxidative capacity and the tendency of the pharmaceutical molecules to be adsorbed. Based on the global 523 removal efficiency of the system, micropollutants clearly differentiate into two groups: the biodegradable 524 pharmaceuticals and the recalcitrant ones. The latter group is formed by CBZ and CIP, compounds 525 presenting high hydrophobicity and complex chemical structure that are very resistant to laccase oxidation even in the presence of redox mediators (Parra Guardado et al. 2019; Hata et al. 2010). Belonging to the biodegradable group, AMX and SMX are antibiotics that possess functional groups prone to be attacked by laccase (OH and $\mathrm{NH}_{2}$, respectively). The highest oxidation rates of $\mathrm{AMX}$ and SMX were achieved when SYR or PCA was present in the reaction medium. Interestingly both mediators follow the hydrogen atom transfer mechanism of reaction in which after oxidation, phenoxyl radicals are produced to act as an electron shuttle between the laccase and substrate (Cañas and Camarero 2010). Indeed, phenoxyl radicals formed were highly reactive and stable to carry out the simultaneous transformation of AMX and SMX. Nonetheless, it is important to note that the high removal obtained for AMX, for SMX especially and to some extent for CIP, could not be totally attributed to laccase-catalyzed oxidation but a combined contribution of adsorption and degradation. As shown in Figure 5, the adsorption of pharmaceuticals reached equilibrium 30 minutes after the start of the reaction, then laccase oxidation effects ongoing to be more evident. In other words, adsorption of micropollutant on immobilized enzyme could have helped and, to some extent, enhanced laccase degradation. Nguyen et al. (2016b) observed similar behavior for the removal of the recalcitrant CBZ and SMX with immobilized laccase on granular activated carbon in a packed bed reactor. These authors suggested that enhancement in laccase degradation for both compounds could possibly be due to the improved electron transfer between laccase and substrate after adsorption on the support surface. Such an effect is especially evident for SMX when SYR was the mediator leading to the complete transformation of the antibiotic in less than $4 \mathrm{~h}$.

The high affinity of the free laccase-SYR system for AMX and SMX was also observed in a previous work (Parra Guardado et al. 2019). Free TVL $\left(1.2 \mathrm{U} \mathrm{mL}^{-1}\right)$ in the presence of SYR reached $50 \%$ removal for AMX in $3 \mathrm{~h}$ and complete elimination for SMX in $1.5 \mathrm{~h}$. In the present investigation, considerably lower 
amounts of immobilized enzyme $\left(0.5 \mathrm{U} \mathrm{mL}^{-1}\right)$ achieved comparable or even higher removal yields for both micropollutants within the same reaction time. These results suggest that the novel immobilization process proposed in this work positively influenced the stability of TVL, which, coupled with the adsorption capacity of the biocatalyst, enhanced the removal of pharmaceutical pollutants.

\subsection{Reusability of immobilized laccase}

The biocatalyst was reused in a total of 9 cycles ( $2 \mathrm{~h}$ each cycle) for the removal of selected micropollutants using SYR as a redox mediator. At the end of each degradation cycle, the biocatalyst was washed with buffer solution (see section 2.7) and added to a fresh solution containing the mixture of pharmaceuticals and mediator.

As shown in Figure 6, the percentage of removal is micropollutant dependant. Even if the dispersion of results seems quite large (for instance, see the bars of errors), some trends can be identified regarding the contribution of the enzymatic reaction to the depletion. Indeed, if the enzymatic degradation contribution is estimated as the difference between the total removal (reaction+adsorption, blue bars) and the adsorption (white bars), for AMX, the enzymatic biodegradation is more important during the first 7 cycles (between 12 to $28 \%$ ), and then it decreases for the last two cycles ( 8 and $3 \%$ respectively). In contrast, for SMX the evolution of this difference is much clear, decreasing continuously for the first 8 cycles (from $32 \%$ to $8 \%$ ), while only the adsorption phenomenon was observed for the last cycle. As expected, CIP and CBZ removal were entirely by adsorption with an average elimination of $30 \%$ and $50 \%$ for each compound (Fig. S2, SI). Nevertheless, explanations are not simple because we have to consider that these experiments were done in mixtures. There is a competition for adsorption sites in such complex systems, and the reactivity of the immobilized laccase towards each one of the molecules studied is also different.

The loss of efficiency observed for the degradation of micropollutants by immobilized enzymes has been extensively reported in different studies, and many explanations could be given: from loss of enzymatic activity to inhibition of the active center of laccase by the accumulation of high molar mass 
products formed during the reaction leading to mass transfer resistance (De Cazes et al. 2014; Ji et al. 2016). Indeed, the possible inhibition of immobilized laccase could be explained by the loss in its capability to transform both antibiotics simultaneously. Whereas SMX was highly removed only in the first two cycles, AMX was continuously transformed for 7 cycles. There is the possibility that interactions between the active biocatalyst and the substrates/by-products formed during the first cycles caused conformational changes in the enzyme that narrowed its capacity to oxidize both compounds. Moreover, the preference for AMX transformation over SMX during the following cycles could be linked to its chemical structure and the presence of functional groups that make AMX more prone to laccase oxidation in comparison to SMX (Yang et al. 2013).

\section{CONCLUSIONS}

In this study, Trametes versicolor laccase was covalently immobilized onto commercial silica gel particles through a novel immobilization process involving the activation of the support with glutaraldehyde in vapor phase. This is the first work reporting the use of this activation technique for the immobilization of laccase on solid supports for bioremediation applications. An experimental design was proposed in order to identify the most important factors involved in the immobilization process. According to the model generated, $\mathrm{pH}$ was the most important factor influencing the immobilization. The conditions found to maximize the biocatalyst activity were $18 \mathrm{~h}$ of GLU activation time, enzyme concentration of 107 $\mathrm{U}, 2 \mathrm{~h}$ of contact time and $\mathrm{pH}$ 7. Overall, in comparison to the free enzyme, immobilization improved enzyme stability over a range of $\mathrm{pH}$ and temperature conditions as well as for long storage.

The potentiality of using the biocatalyst for the removal of pharmaceuticals was evaluated in osmosed water containing a mixture of four representative pharmaceutical micropollutants. High removal yields (40-100\%) were achieved when redox mediators were present in the reaction medium. It was observed that redox mediators generating phenoxyl radicals were the most effective for the biotransformation of the pharmaceuticals, with SYR showing the best performance. Compared to free laccase, immobilized enzyme removed the micropollutants more effectively due to the combined action of 
599 adsorption on the support and laccase catalyzed oxidation. Furthermore, the biocatalyst reusability was 600 proved for the continuous removal of the pharmaceuticals during seven cycles. The results presented in 601 this study show that the novel immobilization process proposed, and the resulting biocatalyst is a promising 602 tool to increase the application of enzymes in bioremediation processes. However, as the use of redox 603 mediators may increase the toxicity of the effluent as well as the cost of the water treatment, further works 604 are needed to find solutions allowing retention and reuse of the mediators.

605

606

607

Declarations

608

609

610

Ethics approval and consent to participate

611

612

Consent for publication

613

Not applicable

614

615

Availability of data and materials

616

The datasets used and/or analyzed during the current study are available from the corresponding author on reasonable request, additional information and results are given in supplementary material.

619

\section{Competing interests}

\section{Funding}



the project POLPHARMA (ANR-15-CE04-0007). CONACYT (Mexico) provided the support provided in the form of PhD studies fellowship No. 410752 (ALPG).

627

\section{Authors' contributions}

ALPG carried out the experimental work of enzymatic degradation of antibiotics with laccases and mediators, SDB worked on the design and analysis of the experimental modelling, MPB designed degradation experiments and contributes to the scientific discussion, JSM supervised all of the work, contributed with the discussions and wrote the whole manuscript. All of the authors revised the manuscript.

\section{Acknowledgements}

The Agence Nationale de la Recherche (ANR, France) is acknowledged for the support provided in the frame of the project POLPHARMA (ANR-15-CE04-0007). ALPG acknowledges the CONACYT (Mexico) for the support provided in the form of PhD studies fellowship No. 410752. We gratefully recognize Dr. Roberto Parra from Monterrey Institute of Technology (Mexico) for kindly providing P. 


\section{References}

Anh TM, Dzyadevych SV, Soldatkin AP, Duc Chien N, Jaffrezic-Renault N, Chovelon JM (2002) Development of tyrosinase biosensor based on $\mathrm{pH}$-sensitive field-effect transistors for phenols determination in water solutions. Talanta 56: 627-634. https://doi:10.1016/S00399140(01)00611-7

Barbosa O, Torres R, Ortiz C, Berenguer-Murcia A, Rodrigues RC, Fernandez-Lafuente R (2013) Heterofunctional supports in enzyme immobilization: From traditional immobilization protocols to opportunities in tuning enzyme properties. Biomacromol 14:2433-2462. https://doi:10.1021/bm400762h

Barrios-Estrada C, Rostro-Alanis M. de J, Parra AL, Belleville MP, Sanchez-Marcano J, Iqbal HMN, Parra-Saldívar R (2018) Potentialities of active membranes with immobilized laccase for Bisphenol A degradation. Int J Biol Macromol 108:837-844. https://doi:10.1016/j.ijbiomac.2017.10.177

Cabana H, Alexandre C, Agathos SN, Jones JP (2009) Immobilization of laccase from the white rot fungus Coriolopsis polyzona and use of the immobilized biocatalyst for the continuous elimination of endocrine disrupting chemicals. Bioresour Technol 100:3447-3458. https://doi:10.1007/s10103-009-0744-6

Cantone S, Ferrario V, Corici L, Ebert C, Fattor D, Spizzo P, Gardossi L (2013) Efficient immobilization of industrial biocatalysts: criteria and constrains for the selection of organic polymeric carriers and immobilization methods. Chem Soc Rev 42:6262-6276. https://doi:10.1039/c3cs35464d

Cañas Al, Camarero S (2010) Laccases and their natural mediators: Biotechnological tools for sustainable eco-friendly processes. Biotechnol Adv 28:694-705. https://doi:10.1016/j.biotechadv.2010.05.002

Celiz MD, Pérez S, Barceló D, Aga DS (2009) Trace analysis of polar pharmaceuticals in wastewater by LC-MS-MS: Comparison of membrane bioreactor and activated sludge systems. J Chromatogr Sci 47:19-25. https://doi:10.1093/chromsci/47.1.19 
De Cazes M, Belleville MP, Petit E, Llorca M, Rodríguez-Mozaz S, De Gunzburg J, Barceló D, SanchezMarcano J (2014) Design and optimization of an enzymatic membrane reactor for tetracycline degradation. Catal Today 236:146-152. https://doi:10.1016/j.cattod.2014.02.051

Destaye AG, Lin CK, Lee CK (2013) Glutaraldehyde vapor cross-linked nanofibrous PVA mat with in situ formed silver nanoparticles. ACS Appl Mater Interfaces 5:4745-4752. https://doi:10.1021/am401730x

Ebele AJ, Abdallah MA, Harrad S (2017) Pharmaceuticals and personal care products (PPCPs) in the freshwater aquatic environment. Emerg Contam 3:1-16. https://doi:10.1016/j.emcon.2016.12.004

Fortes CCS, Daniel-da-Silva AL, Xavier AMRB, Tavares APM (2017) Optimization of enzyme immobilization on functionalized magnetic nanoparticles for laccase biocatalytic reactions, Chem Eng Process Process Intensif. 117:1-8. https://doi:10.1016/j.cep.2017.03.009

Galvão WS, Pinheiro BB, Golçalves LRB, de Mattos MC, Fonseca TS, Regis T, Zampieri D, dos Santos JCS, Costa LS, Correa MA, Bohn F, Fechine PBA (2018) Novel nanohybrid biocatalyst: application in the kinetic resolution of secondary alcohols. J Mater Sci 53:14121-14137. https://doi.org/10.1007/s10853-018-2641-5

Gamallo M, Moldes-Diz Y, Eibes G, Feijoo G, Lema JM, Moreira MT (2018) Sequential reactors for the removal of endocrine disrupting chemicals by laccase immobilized onto fumed silica $\begin{array}{llll}\text { microparticles. } & \text { Biocatal } & \text { 36:254-264. }\end{array}$ https://doi:10.1080/10242422.2017.1316489

George A, Radhakrishnan GA, Joseph KT (1984) Grafting of Acrylonitrile onto Gelatin in Zinc Chloride Medium. J Macromol Sci Part - Chem 21:179-191. https://doi.org/10.1080/00222338408056547

Grandclément C, Seyssiecq I, Piram A, Wong-Wah-Chung P, Vanot G, Tiliacos N, Roche N, Doumenq P (2017) From the conventional biological wastewater treatment to hybrid processes, the evaluation of organic micropollutant removal: A review. Water Res 111: 297-317. 
https://doi:10.1016/j.watres.2017.01.005

Grenni P, Ancona V, Barra Caracciolo A (2018) Ecological effects of antibiotics on natural ecosystems : A review. Microchem. J. 136:25-39. https://doi:10.1016/j.microc.2017.02.006

Hata T, Shintate H, Kawai S, Okamura H, Nishida T (2010) Elimination of carbamazepine by repeated treatment with laccase in the presence of 1-hydroxybenzotriazole. J Hazard Mater 181:11751178. https://doi:10.1016/j.jhazmat.2010.05.103

Ji C, Hou J, Wang K, Zhang Y, Chen V (2016) Biocatalytic degradation of carbamazepine with immobilized laccase-mediator membrane hybrid reactor. J Membr Sci 502:11-20. https://doi.org/10.1016/j.memsci.2015.12.043

Ji C, Nguyen LN, Hou J, Hai FI, Chen V (2017) Direct immobilization of laccase on titania nanoparticles from crude enzyme extracts of P. ostreatus culture for micro-pollutant degradation. Sep Purif Technol 178 :215-223. https://doi:10.1016/j.seppur.2017.01.043

Jiang DS, Long SY, Huang J, Xiao HY, Zhou JY (2005) Immobilization of Pycnoporus sanguineus laccase on magnetic chitosan microspheres. Biochem Eng J 25:15-23. https://doi:10.1016/j.bej.2005.03.007

Lloret L, Eibes G, Lú-Chau TA, Moreira MT, Feijoo G, Lema JM (2010) Laccase-catalyzed degradation of anti-inflammatories and estrogens. Biochem Eng J 51:124-131. https://doi:10.1016/j.bej.2010.06.005

Lloret L, Hollmann F, Eibes G, Feijoo G, Moreira MT, Lema JM (2012) Immobilisation of laccase on Eupergit supports and its application for the removal of endocrine disrupting chemicals in a packed-bed reactor. Biodegradation 23:373-386. https://doi:10.1007/s10532-011-9516-7

Lowry OH, Rosebrough NJ, Farr AL, Randall RJ (1951) Protein measurement with the Folin phenol reagent. J Biol Chem 193:265-275. https://doi:10.1016/0304-3894(92)87011-4

Luo Y, Guo W, Ngo HH, Nghiem LD, Hai Fl, Zhang J, Liang S Wang XC (2014) A review on the occurrence of micropollutants in the aquatic environment and their fate and removal during wastewater treatment. Sci Total Environ 473-474:619-641. 
https://doi:10.1016/j.scitotenv.2013.12.065

Misra N, Kumar V, Goel NK, Varshney L (2014) Laccase immobilization on radiation synthesized epoxy functionalized polyethersulfone beads and their application for degradation of acid dye. Polymer 55:6017-6024. http://dx.doi.org/10.1016/j.polymer.2014.09.035

Morsi R, Muhammad B, Iqbal HMN, Ashraf SS (2020) Laccases and peroxidases: The smart, greener and futuristic biocatalytic tools to mitigate recalcitrant emerging pollutants. Sci Total Environ 714:136572. https://doi.org/10.1016/j.scitotenv.2020.136572

Naghdi M, Taheran M, Brar SK, Kermanshahi-pour A, Verma M, Surampalli RY (2018) Removal of pharmaceutical compounds in water and wastewater using fungal oxidoreductase enzymes. Environ Pollut 234:190-213. https://doi:10.1016/j.envpol.2017.11.060

Nguyen LN, van de Merwe JP, Hai Fl, Leusch FDL, Kang J, Price WE, Roddick F, Magram SF, Nghiem LD (2016a) Laccase-syringaldehyde-mediated degradation of trace organic contaminants in an enzymatic membrane reactor: Removal efficiency and effluent toxicity. Bioresour Technol 200:477-484. https://doi:10.1016/j.biortech.2015.10.054

Nguyen LN, Hai Fl, Dosseto A, Richardson C, Price WE, Nghiem LD (2016b) Continuous adsorption and biotransformation of micropollutants by granular activated carbon-bound laccase in a packed-bed enzyme reactor. Bioresour Technol 210:108-116. https://doi:10.1016/j.biortech.2016.01.014

Parra Guardado AL, Belleville MP, Rostro Alanis M de J, Parra Saldivar R, Sanchez-Marcano J, (2019) Effect of redox mediators in pharmaceuticals degradation by laccase: A comparative study Process Biochem 78:123-131. https://doi:10.1016/J.PROCBIO.2018.12.032

Patel SKD, Kalia VC, Choi JH, Haw JR, Kim IW, Lee JK (2014) Immobilization of Laccase on SiO2 Nanocarriers Omproves Its Stability and Reusability. J Microbiol Biotechnol 24:639-647. https://doi:10.4014/jmb.1401.01025

Pezzella C, Russo ME, Marzocchella A, Salatino P, Sannia G (2014) Immobilization of a pleurotus ostreatus laccase mixture on perlite and its application to dye decolourisation. Biomed Res Int 
2014:1-11. https://doi.org/10.1155/2014/308613

Ramírez-Cavazos LI, Junghanns C, Nair R, Cárdenas-Chávez DL, Hernández-Luna C, Agathos SN, Parra R (2014) Enhanced production of thermostable laccases from a native strain of Pycnoporus sanguineus using central composite design. J Zhejiang Univ Sci B 15:343-352. https://doi:10.1631/jzus.B1300246

Rodrigues RC, Ortiz C, Berenguer-Murcia A, Torres R, Fernández-Lafuente R (2013) Modifying enzyme activity and selectivity by immobilization. Chem Soc Rev 42:6290-6307. https://doi:10.1039/c2cs35231a

Sanchez A, Cruz J, Rueda N, dos Santos JCS, Torres R, Ortiz C, Villalonga R, Fernandez-Lafuente R (2016) Inactivation of immobilized trypsin under dissimilar conditions produces trypsin molecules with different structures. RSC Adv 6:27329-27334. https://doi.org/10.1039/C6RA03627A

Shakerian F, Zhao J, Li SP (2020) Recent development in the application of immobilized oxidative enzymes for bioremediation of hazardous micropollutants - A review. Chemosphere 239:124716. https://doi.org/10.1016/j.chemosphere.2019.124716

Shao B, Liu Z, Zeng G, Liu Y, Yang X, Zhou C, Chen M, Liu Y, Jiang Y, Yan M (2019) Immobilization of laccase on hollow mesoporous carbon nanospheres: Noteworthy immobilization, excellent stability and efficacious for antibiotic contaminants removal. J Hazard Mater 362:318-326. https://doi:10.1016/j.jhazmat.2018.08.069

Sheldon RA, van Pelt S (2013) Enzyme immobilisation in biocatalysis: Why, what and how. Chem Soc Rev 42:6223-6235. https://doi:10.1039/c3cs60075k

Songulashvili G, Jimenéz-Tobón GA, Jaspers C, Penninckx MJ (2012) Immobilized laccase of Cerrena unicolor for elimination of endocrine disruptor micropollutants. Fungal Biol 116:883-889. https://doi:10.1016/j.funbio.2012.05.005

Spinelli D, Fatarella E, Di Michele A, Pogni R (2013) Immobilization of fungal (Trametes versicolor) laccase onto Amberlite IR-120 H beads: Optimization and characterization. Process Biochem 
48:218-223. https://doi:10.1016/j.procbio.2012.12.005

Tavares APM, Silva CG, Dražić G, Silva AMT, Loureiro JM, Faria JL (2015) Laccase immobilization over multi-walled carbon nanotubes: Kinetic, thermodynamic and stability studies. J Colloid Interface Sci 454:52-60. https://doi:10.1016/j.jcis.2015.04.054

Teodosiu C, Gilca AF, Barjoveanu G, Fiore S (2018) Emerging pollutants removal through advanced drinking water treatment: A review on processes and environmental performances assessment. J Clean Prod 197: 1210-1221. https://doi:10.1016/J.JCLEPRO.2018.06.247

Wang Y, Chen X, Liu J, He F, Wang R (2012) Immobilization of laccase by Cu2+chelate affinity interaction on surface-modified magnetic silica particles and its use for the removal of 2,4dichlorophenol. Environ Sci Pollut Res 20:6222-6231. https://doi:10.1007/s11356-013-1661-6

Wishart DS, Knox C, Guo AC, Shrivastava S, Hassanali M, Stothard P, Chang Z, Woolsey J (2006). Drugbank: a comprehensive resource for in silico drug discovery and exploration. Nucleic Acids Res. Jan 1;34 (Database issue):D668-72. 16381955. https://www.drugbank.ca/. Accessed 20 June 2019.

Yang S, Hai Fl, Nghiem LD, Price WE, Roddick F, Moreira MT, Magram SF (2013) Understanding the factors controlling the removal of trace organic contaminants by white-rot fungi and their lignin modifying enzymes: A critical review. Bioresour Technol 141:97-108. https://doi:10.1016/j.biortech.2013.01.173

Zdarta J, Meyer AS, Jesionowski T, Pinelo M (2018) Developments in support materials for immobilization of oxidoreductases: A comprehensive review. Adv Colloid Interface Sci 258:120. https://doi:10.1016/j.cis.2018.07.004

Zheng F, Cui BK, Wu XJ, Meng G, Liu HX, Si J (2016) Immobilization of laccase onto chitosan beads to enhance its capability to degrade synthetic dyes. Int. Biodeterior Biodegrad 110:69-78. https://doi:10.1016/j.ibiod.2016.03.004 
Table 1. Factor levels used according to the $2^{3}$ factorial design.

\begin{tabular}{llll}
\hline \multirow{2}{*}{ Variable } & Level & & \\
\cline { 2 - 4 } & $\mathbf{- 1}$ & $\mathbf{0}$ & $\mathbf{1}$ \\
\hline $\mathrm{X}_{1}:$ Concentration of enzyme solution $(\mathrm{U})$ & 107 & 203 & 300 \\
$\mathrm{X}_{2}:$ Immobilization time $(\mathrm{h})$ & 1 & 1.5 & 2 \\
$\mathrm{X}_{3}: \mathrm{pH}$ of enzyme solution & 4.33 & 5.66 & 7 \\
\hline
\end{tabular}


Table 2. Values for the response (activity of the biocatalyst) according to the $2^{3}$ factorial design

\begin{tabular}{llrrll}
\hline \multirow{2}{*}{ Assay } & Factors & & \multicolumn{3}{l}{$\begin{array}{l}\text { Activity of immobilized laccase } \\
\left(\mathbf{U} \mathbf{g}^{-1} \text { solid }\right)\end{array}$} \\
\cline { 2 - 6 } & $\mathbf{X}_{1}$ & $\mathbf{X}_{2}$ & $\mathbf{X}_{3}$ & Observed value & Predicted value \\
\hline 1 & -1 & -1 & -1 & 2.77 & 2.52 \\
2 & -1 & -1 & 1 & 3.90 & 3.83 \\
3 & -1 & 1 & -1 & 2.92 & 2.77 \\
4 & -1 & 1 & 1 & 7.26 & 6.64 \\
5 & 1 & -1 & -1 & 1.73 & 1.90 \\
6 & 1 & -1 & 1 & 2.80 & 3.79 \\
7 & 1 & 1 & -1 & 3.25 & 3.41 \\
8 & 1 & 1 & 1 & 2.83 & 2.73 \\
9 & 0 & 0 & 0 & 2.50 & 2.37 \\
10 & 0 & 0 & 0 & 2.23 & 2.37 \\
11 & -1 & -1 & -1 & 2.22 & 2.52 \\
12 & -1 & -1 & 1 & 3.81 & 3.83 \\
13 & -1 & 1 & -1 & 2.66 & 2.77 \\
14 & -1 & 1 & 1 & 5.97 & 6.64 \\
15 & 1 & -1 & -1 & 2.02 & 1.90 \\
16 & 1 & -1 & 1 & 4.83 & 3.79 \\
17 & 1 & 1 & -1 & 3.63 & 3.41 \\
18 & 1 & 1 & 1 & 2.57 & 2.73 \\
19 & 0 & 0 & 0 & 2.50 & 2.37 \\
20 & 0 & 0 & 0 & 2.23 & 2.37 \\
\hline
\end{tabular}

$\mathrm{X} 1=$ concentration enzyme solution; $\mathrm{X} 2=$ immobilization time; $\mathrm{X} 3=\mathrm{pH}$ enzyme solution. 
Table 3. Analysis of variance (ANOVA) for the first-order model for the activity of immobilized laccase.

\begin{tabular}{llllll}
\hline Factor & SS & df & MS & $\boldsymbol{F}$ & $\boldsymbol{p}$ \\
\hline Curvature & 3.76 & 1 & 3.76 & 13.59 & 0.0031 \\
$\mathrm{X}_{1}$ & 3.86 & 1 & 3.86 & 13.97 & 0.0028 \\
$\mathrm{X}_{2}$ & 3.08 & 1 & 3.08 & 11.12 & 0.0059 \\
$\mathrm{X}_{3}$ & 10.17 & 1 & 10.17 & 36.79 & 0.0001 \\
$\mathrm{X}_{1}: \mathrm{X}_{2}$ & 1.69 & 1 & 1.69 & 6.13 & 0.0292 \\
$\mathrm{X}_{1}: \mathrm{X}_{3}$ & 3.97 & 1 & 3.97 & 14.36 & 0.0026 \\
$\mathrm{X}_{1}: \mathrm{X}_{2}: \mathrm{X}_{3}$ & 6.61 & 1 & 6.61 & 23.89 & 0.0004 \\
Error & 3.32 & 12 & 0.28 & & \\
Total SS & 36.46 & 19 & & & \\
\hline
\end{tabular}

$\mathrm{SS}=$ sum of squares; $\mathrm{df}=$ degrees of freedom; $\mathrm{MS}=$ mean square; $\mathrm{F}=\mathrm{F}$ distribution value; $\mathrm{X}_{1}=$ concentration enzyme solution; $X_{2}=$ immobilization time; $X_{3}=p H$ enzyme solution.

$R^{2}=0.90899 ; \operatorname{Adj}-R^{2}=0.8559$ 
Table 4. Immobilization yield and activity in the immobilization of laccases on 3-Aminopropylfunctionalized silica microparticles at $\mathrm{pH} 7$.

\begin{tabular}{llll}
\hline Enzyme & $\begin{array}{l}\text { Activity } \\
\mathbf{( U ~ g ~}^{-1} \text { biocatalyst) }\end{array}$ & $\begin{array}{l}\text { Immobilization capacity } \\
\mathbf{( m g ~ g}^{-1} \text { biocatalyst) }\end{array}$ & $\begin{array}{l}\text { Bound protein } \\
\text { (\%) }\end{array}$ \\
\hline MTL & $4.5 \pm 2.1$ & $37.9 \pm 15.4$ & $21.6 \pm 10.3$ \\
PSL & 0.76 & N.D & N.D \\
TVL & $13.6 \pm 2.3$ & $13.5 \pm 6.2$ & $35.4 \pm 4.7$ \\
\hline
\end{tabular}

N.D: Not determined due to the low activity measured 


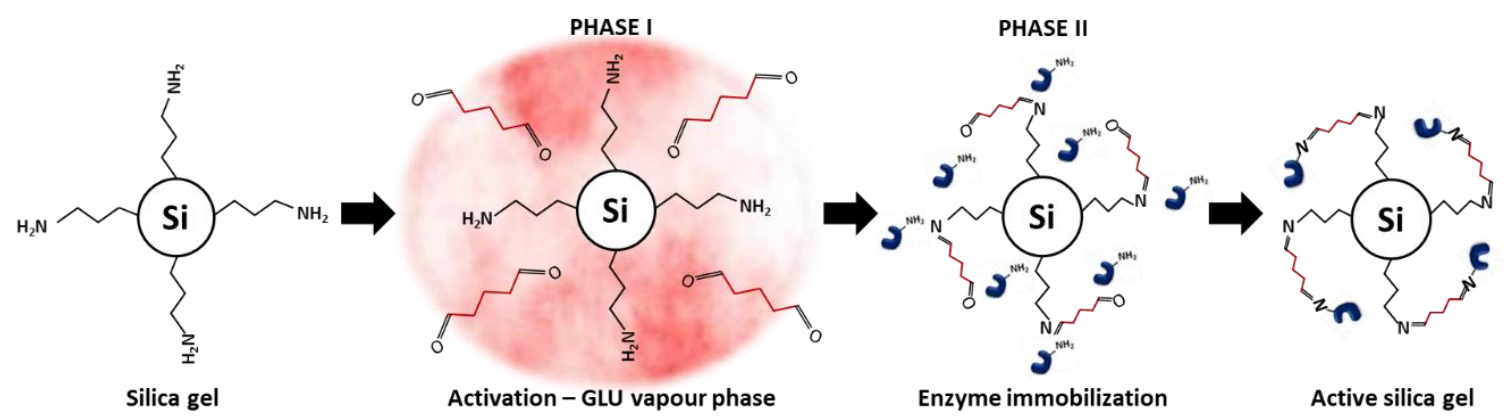

Fig. 1. Covalent immobilization of laccase on silica gel via activation with glutaraldehyde (GLU)in vapor phase. 


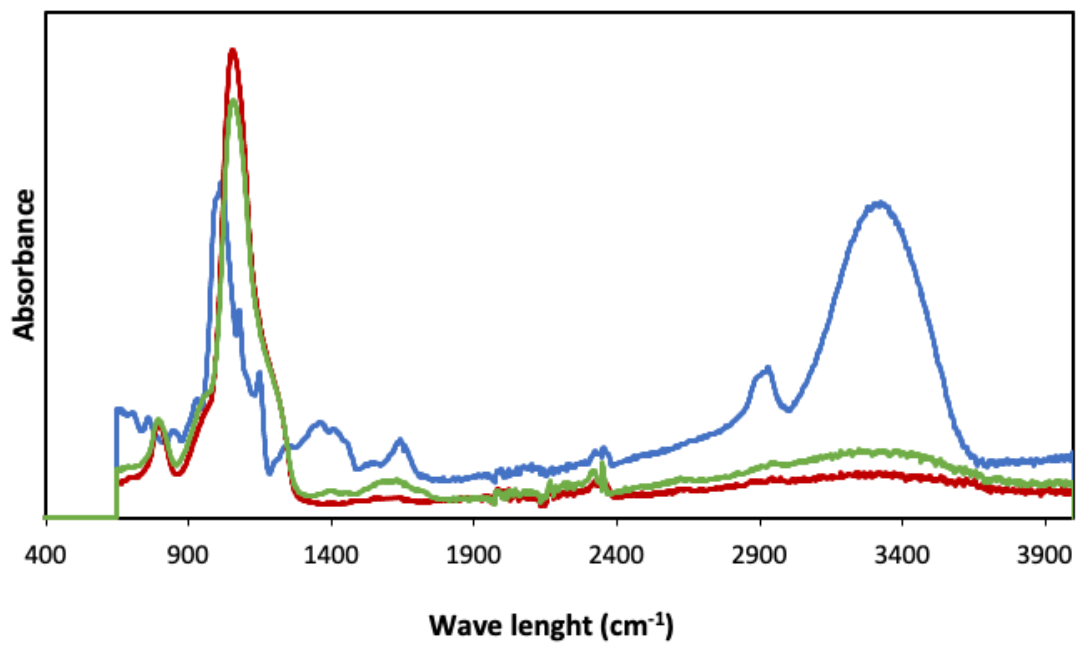

Fig. 2. FITR-ATR spectra of laccase (blue line), untreated 3-aminopropyl functionalized silica gel (red line) and TVL immobilized on silica gel particles (green line). 

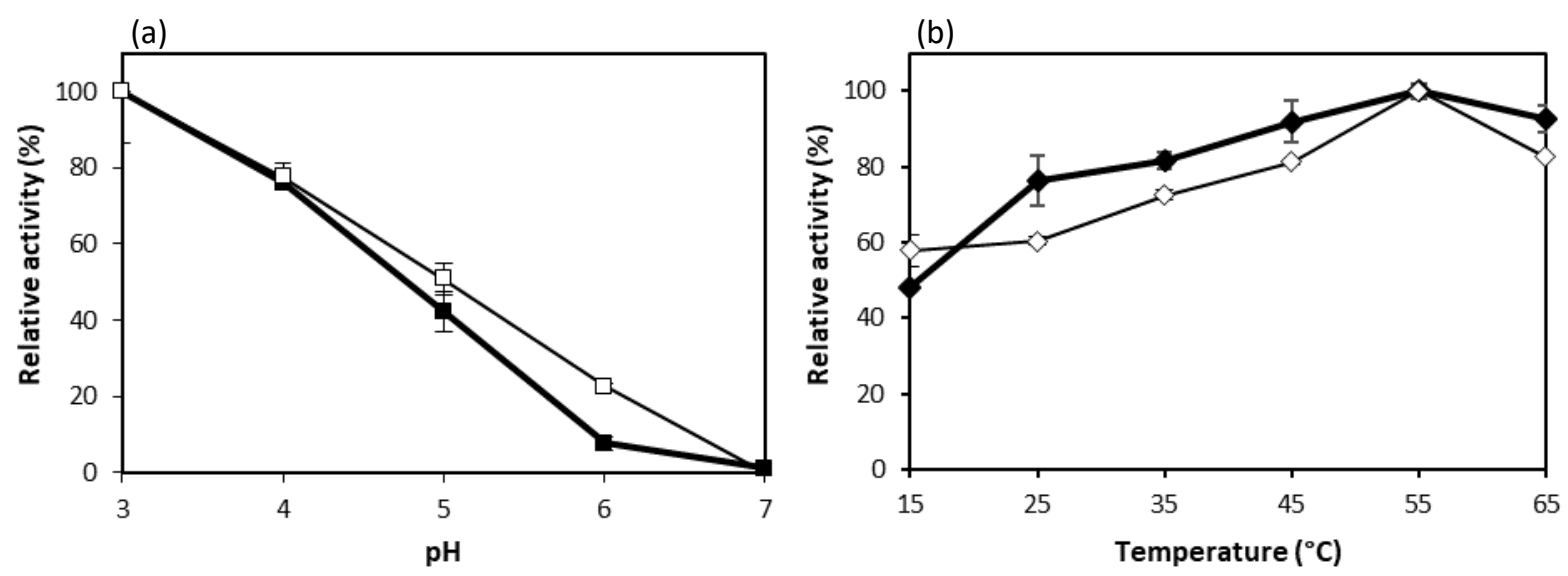

Fig. 3. Effect of (a) pH and (b) temperature on free and immobilized TVL. $\mathrm{pH}(3-7)$ and temperature $\left(15-65^{\circ} \mathrm{C}\right)$ were tested with $1 \mathrm{mM}$ ABTS in $0.1 \mathrm{M}$ citrate-phosphate buffer. Free and immobilized enzymes are represented by open and closed symbols respectively. 
(a)

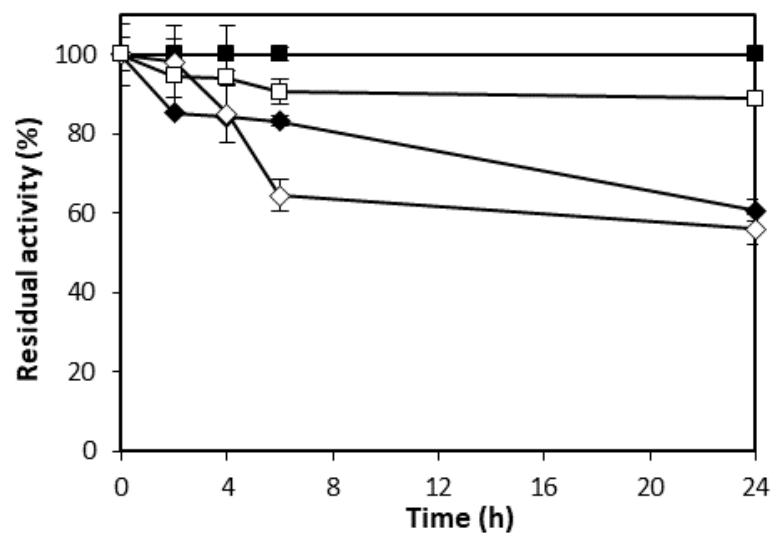

(b)

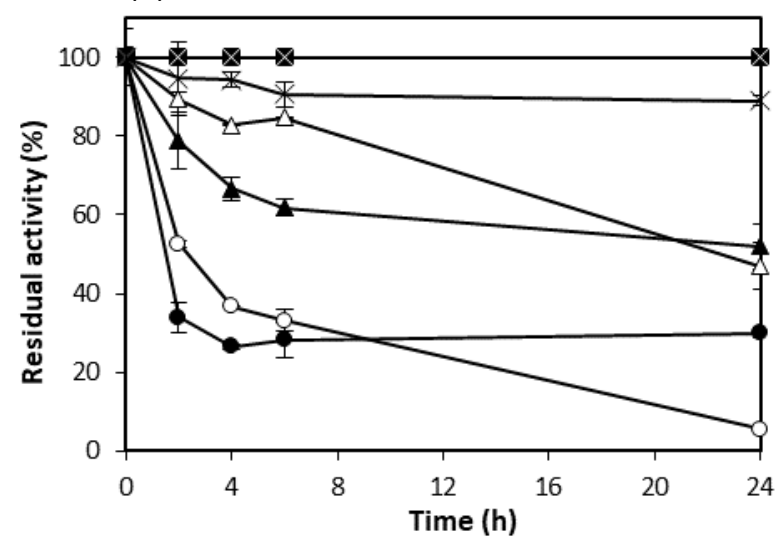

Fig. 4. (a) pH and (b) thermal stability of free and immobilized TVL on silica particles. pH values: 4 (•) and $7(\square)$. Temperature values: $25^{\circ} \mathrm{C}(\mathbf{x}), 45^{\circ} \mathrm{C}(\mathbf{\Delta})$ and $55^{\circ} \mathrm{C}(\bullet)$. The open and closed symbols represent free enzyme and immobilized enzyme respectively. 
(a)

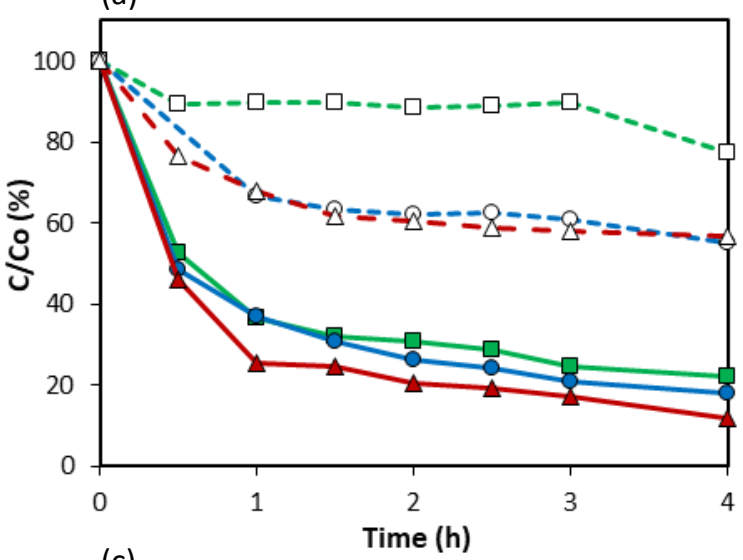

(c)

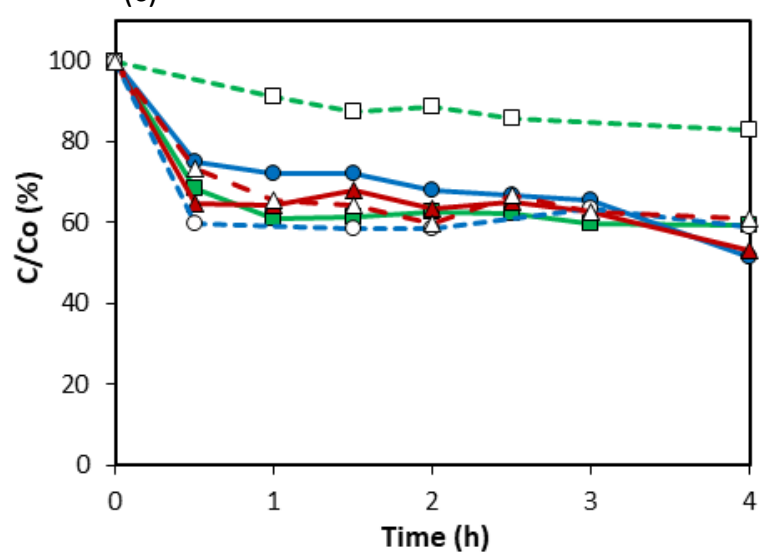

(b)

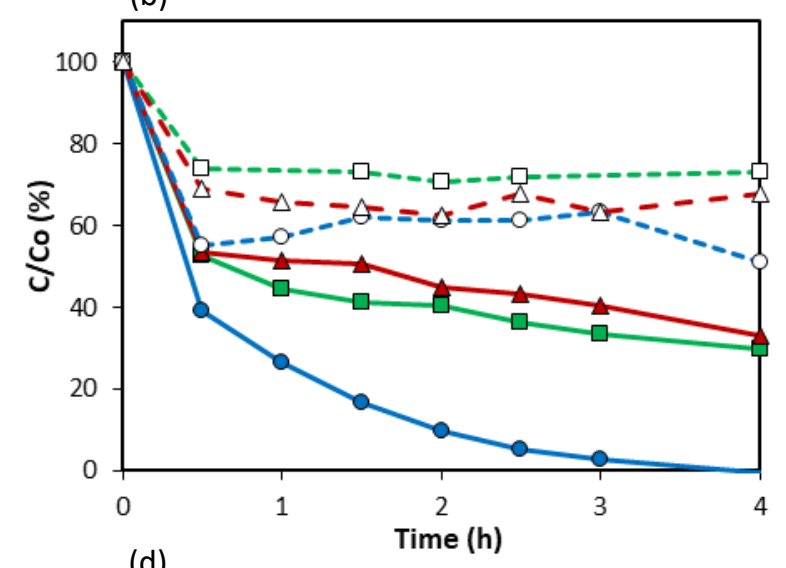

(d)

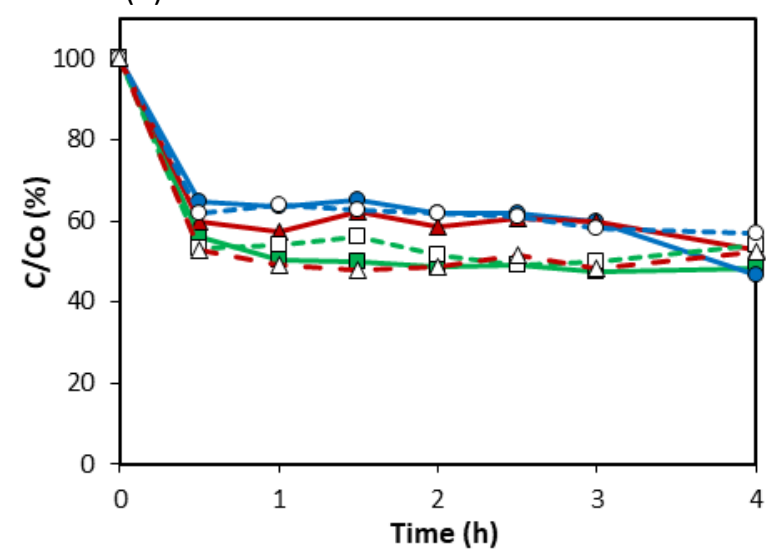

Fig. 5. Residual concentration of (a) $A M X$, (b) SMX, (c) CIP and (d) CBZ in mixture after $4 \mathrm{~h}$ treatment with immobilized TVL on silica particles and different redox mediators: ABTS $(\square)$, SYR $(\bullet)$ and PCA $(\mathbf{\Delta})$. The open symbols represent the removal by adsorption on the support with inactivated laccase. Measurements were carried out by duplicate, with standard deviations less than $15 \%$. 

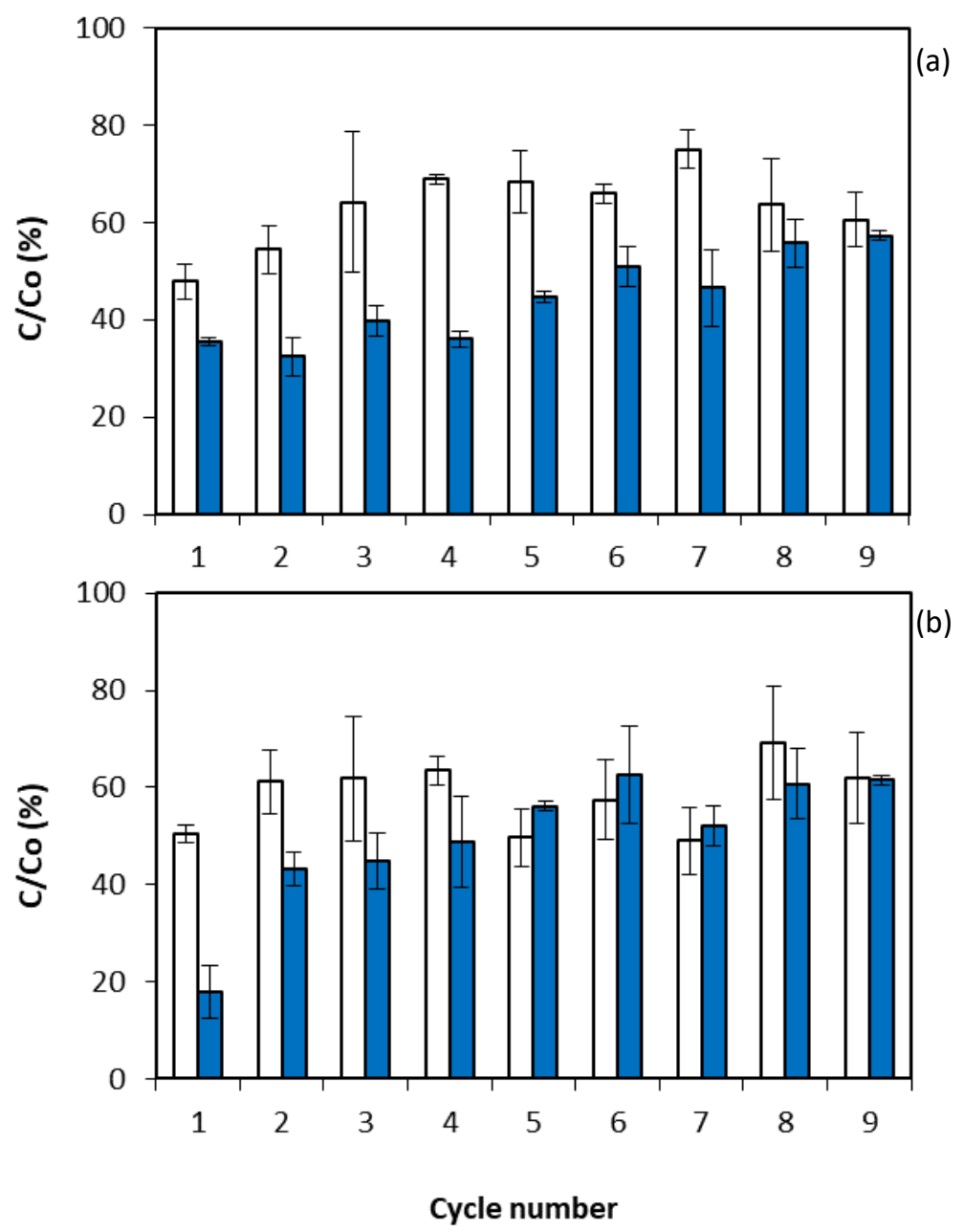

Fig. 6. Removal of (a) $A M X$ and (b) SMX in a mixture by immobilized laccase and SYR as redox mediator in consecutive cycles at $25^{\circ} \mathrm{C}$ and $\mathrm{pH} 7$ (blue bars). Adsorption of each micropollutant on the support with inactivated laccase is represented by white bars. 